\title{
PARTISIPASI CIVITAS AKADEMIKA DALAM PENGELOLAAN ECO-KAMPUS DAN PEMANFAATAN LIMBAH ORGANIK TUMBUHAN UNTUK PEMBUATAN PUPUK KOMPOS DI LINGKUNGAN KAMPUS UIN RADEN INTAN LAMPUNG
}

\author{
Nasor \\ Universitas Islam Negeri (UIN) Raden Intan Lampung \\ Email: nasor@gmail.com \\ Jasmadi \\ Universitas Islam Negeri (UIN) Raden Intan Lampung \\ Email: jasmadi@gmail.com
}

\begin{abstract}
Environmental problems and management efforts are increasingly complex covering various aspects, while human understanding of the environment is still limited. Limited supporting infrastructure and the availability of reliable human resources (HR) are the main factors that need attention. The academic community has great potential in building an integrated, comprehensive and sustainable environmental management. Therefore, it is necessary to develop a concept that can unite all elements in an environmental management system. From this system, it is hoped that it can build awareness about the importance of environmental management. This research takes the type of field research (field research), namely the type of research carried out in a place, namely research conducted in real life. Regarding the data source in this study, the opinions of the campus users are in preserving and protecting the campus environment. The results of the research are efforts to strengthen the participation of campus residents to develop their awareness of environmental preservation towards sustainable development based on the Green Campus concept. Forms of participation of campus residents in environmental preservation are through routine activities in the form of independent, integrated and mutual cooperation as a form of empowerment. In realizing a green, clean, orderly, neat, beautiful and comfortable campus; involving campus residents can participate in accordance with their respective main duties. This reflects the awareness of campus residents in environmental preservation based on the green campus concept of sustainable development.
\end{abstract}

Keywords: Academic Community Participation, Eco-Campus Management, and Utilization of Organic Waste.

\begin{abstract}
Abstrak
Masalah lingkungan dan upaya pengelolaannya semakin kompleks mencakup berbagai aspek, sementara itu pemahaman manusia terhadap lingkungan hidup masih terbatas. Keterbatasan infrastruktur pendukung yang diperlukan dan ketersediaan sumberdaya manusia (SDM) yang handal merupakan faktor utama yang perlu diperhatikan. Civitas akademika adalah potensi besar dalam membangun pengelolaan lingkungan yang integrated, comprehensive dan sustainable. Karena itu perlu dikembangkan sebuah konsep yang bisa menyatukan semua elemen dalam sebuah sistem pengelolaan lingkungan. Dari sistem ini diharapkan bisa membangun kesadaran tentang pentingnya sebuah pengelolaan lingkungan hidup. Penelitian ini mengambil jenis penelitian lapangan (field research) yaitu jenis penelitian yang dilakukan di suatu tempat yaitu penelitian yang dilakukan
\end{abstract}


dalam kehidupan sebenarnya. Mengenai sumber data dalam penelitian ini adalah pendapat para civitas pengguna kampus dalam melestarikan dan menjaga lingkungan hidup kampus. Hasil penelitian yaitu upaya penguatan partisipasi warga kampus untuk menumbuh-kembangkan kesadarannya dalam pelestarian lingkungan hidup menuju pembangunan berkelanjutan berbasis konsep Green Campus. Bentuk-bentuk partisipasi warga kampus dalam pelestarian lingkungan hidup yaitu melalui kegiatan rutin berupa pengelolaan sampah yang dilakukan mandiri, terpadu dan gotong royong sebagai bentuk pemberdayaan. Dalam mewujudkan kampus hijau, bersih, tertib, rapi, indah dan nyaman; melibatkan warga kampus dapat berpartisipasi sesuai dengan tupoksinya masing-masing. Hal ini mencerminkan adanya kesadaran warga kampus dalam pelestarian lingkungan hidup berdasar konsep green campus pada pengembangan berkelanjutan.

Kata kunci: Partisipasi Civitas Akademika, Pengelolaan Eco-Kampus, dan Pemanfaatan Limbah Organik.

\section{A. Pendahuluan}

Permasalahan lingkungan kampus merupakan masalah bersama yang membutuhkan sinergitas masyarakat kampus, termasuk didalamnya adalah civitas akademika. Sebagai kalangan akademisi, pemikiran kedepan tentang masalah lingkungan sangat dinanti oleh masyarakat karena tentunya kualitas lingkungan yang baik akan menopang kehidupan yang baik. Lingkungan hidup seringkali tidak menjadi prioritas yang tinggi dan seringkali menjadi sub agenda yang pada akhirnya larut dan tenggelam dalam tema - tema kampanye yang lebih luas dan abstrak. Isu - isu lingkungan yang masuk dalam mainstream kampus lebih banyak pada hal- hal yang sifatnya temporer dan terkesan reaksioner seperti bencana alam, kecelakaan di hutan atau perusakan hutan.Cara penanggulangannya sementara ini belum sampai pada akar masalah lingkungan yang terjadi pada saat ini. Akibat dampak dari kegiatan itu hanya akan melahirkan ketidak percayaan pada mereka yang melakukan penanggulangannya. Perusakan lingkungan terus berjalan tanpa melihat siapa sesunggguhnya yang melakukan dan membuat tekanan sehingga semua bencana itu terjadi terus menerus tanpa henti.

Upaya pengelolaan lingkungan kampus semakin kompleks yang mencakup berbagai aspek yang sangat luas, sementara itu pemahaman manusia terhadap lingkungan hidup masih jauh dari sempurna. Keterbatasan infrastruktur pendukung yang diperlukan dan ketersediaan sumberdaya manusia (SDM) yang handal dan penuh komitmen. Menurut Rektor UINRIL komitmen sangat diperlukan untuk kerjasama dalam pengembangan kampus hijau. Adanya komitmen ini akan berhasil menciptakan menuju kampus hijau dan kita harus dapat memberikan contoh dan mengubah gaya hidup kita serta masyarakat sekitar kita. ${ }^{1}$ Merupakan factor utama yang perlu diperhatikan dan dikembangkan, masalah keterampilan dan wawasan yang dimiliki oleh pihak

${ }^{1}$ Moh. Mukri (Rektor UINRIL), Forum Kampus Hijau PTKI Terbentuk, dalam Majalah Raden Intan UINRIL, Edisi XXII, Tahun 2019, h. 17. 
yang berkompeten dalam pengelolaan lingkungan bukan alasan bagi pengelolaan lingkungan.

Insan akademis adalah orang-orang yang memiliki potensi besar dalam pengelolaan lingkungan kampus. Karena itu perlu dikembangkan rancangan yang dapat menyatukan semua elemen kampus dalam sistem pengelolaan lingkungan. Dari system yang dikembangkan diharapkan dapat menumbuhkan kesadaran tentang arti pentingnya dalam pengelolaan lingkungan hidup dalam kampus. Achmad Santosa menegaskan bahwa ada hubungan erat antara pemangku kebijakan yang baik dengan pengelolaan lingkungan hidup yang baik. Penyelenggara kebijakan yang baik akan mempengaruhi dan menentukan pengelolaan lingkungan hidup yang baik, dan pengelolaan lingkungan hidup yang baik mencerminkan tingkat penyelenggara kebijakan yang baik. Tegasnya, tanpa penyelenggara kebijakan yang baik, sulit mengharapkan akan adanya pengelolaan lingkungan hidup yang baik.

Melaluisistem yang dibangun merupakan cara yang komprehensif untuk menanggulangi permasalahan lingkungan hidup. Dari system yang dibangun akan menemukan cara merumuskan masalah secara lebih luas serta menyeluruh untuk dapat ditangani secara baik. Pendekatan system ini memungkinkan prinsip pengorganisasian interdisipliner yang terintegrasi. Sehingga keadaannyaakan sesuai dengan yang dikehendaki dan adanya dinamisasi pengelolaan lingkungan hidup. Di dalam sistem menunjukan adanyasaling berhubungan satu sama lain dalam pengertian tentang metode, sehingga akan terwujud kerjasama antara yang atu dengan lainnya.

Tinjauan kesisteman merupakan suatu cara pandang terhadap realitas empiris berbagai kelompok yang mempunyai komponen bagian dalam hubungan dinamis. Karakteristik sistem yaitu memiliki kehendak atau tujuan, setiap elemenelemen komponen atau variabel yang ada membentuk kualitas karakteristik keseluruhan sistem, bukan dirinya sendiri, elemen-elemen sistem selalu berada dalam hubungan dinamis dengan masukan yang selalu masuk dan keluaran yang selalu keluar, sistem terbuka memiliki interrelasi diantara variabel-variabelnya, dan setiap sistem mempunyai sasaran atau arah, sedangkan kerja atau proses mencapai sasaran tersebut disebut kerja administrasi sistem. ${ }^{2}$

Unsur-unsur yang terdapat dalam sistem atau eco-sistem kampus UIN Raden Intan Lampung yaitu SDM civitas akademika yang meliputi Dosen, Tenaga Tendik, mahasiswa dan tenaga clenning servis, satpam dan para pengguna fasilitas kampus seperti para pedagang di seputaran kampus. Unsur lain berupa lahan yang ditumbuhi rumput dan pohon-pohon rindang yang melahirkan sampah organik. Kampus dengan lahan penghijauan yang cukup luas pada setiap harinya menhasilkan sampah organik yang cukup banyak. Namun hasil limbah tersebut belum termanfaatkan, bahkan dimusnahkan dengan dilakukan

2 https://www.academia.edu/18121109/Materi_Karakteristik_Sistem, diakses pada 18 Agustus 2020. 
pembakaran. Masalah penataan lingkungan kampus masjadi masalah yang penting untuk diperhatikan guna menjaga ketertiban dan kebersihan lingkungan sehingga kampus menjadi bersih dan indah terbebas dari sampah.

Pemanfaatan sampah organik untuk dijadikan pupuk kompos, agar segala sesuatuyang berasal dari alam dikembalikan lagi ke alam dengan bentuk lain yaitu pupuk organik, mengingat lahan kampus dengan tekstur tanah urug yang berasal dari tanah padas, bahkan di sekitaran embung berasal dari tanah liat, maka tingkat kepadatan sangat pekat sehingga akar tumbuhan tidak dapat berkembang dengan baik, sebagai akibat dari hal tersebut tumbuhan tidak bisa tumbuh dengan subur, dalam jangka waktu tertentu tanaman akan mudah mati karena kehabisan nutrisi.

Karena itu pupuk organik yang terbuat dari bahan sampah daun dan bekas potongan rumput dapat dimanfaatkan untuk pemupukan tanaman di lingkungan kampus, dimasukkan ke dalam lobang bio-pori sudah ada sehingga pohon-pohon akan mendapat nutrisi dalam rangka kelangsungan hidupnya. Pohon akan tetap menjadi tetap subur dan hijau, bahkan untuk langkah selanjutnya dibuat tamantaman bunga dan tanaman hias untuk menghias keindahan kampus. ${ }^{3}$

Masalah isu lingkungan hidup pada era globalisasi ini, sangat menjadi perhatian dan pembicaraan di tingkat dunia, masalah lingkungan hidup di Indonesia dan dunia beserta penyebabnya. Jika berbagai permasalahan lingkungan ini tidak dicari solusi yang keberlanjutan, kehidupan manusia di bumi akan mengkhawatirkan. Hal ini dikarenakan alam yang menjadi sumber pemenuhan segala kebutuhan hidup manusia, yaitu penyedia udara, air, makanan, obat-obatan, estetika, dan lainnya akan mengalami kerusakan. Kerusakan alam berarti akan merusakdaya dukung kehidupan manusia

Pencemaran lingkungan hidup. Polusi udara, air dan tanah memerlukan waktu jutaan tahun agar dapat normal kembali. Sektor Industri dan asap kendaraan bermotor adalah sumber pencemaran utama. Logam berat, nitrat dan plastik beracun bertanggung jawab atas berbagai pencemaran yang ada. Sementara polusi air disebabkan oleh tumpahan minyak, hujan asam, limpasan perkotaan. Dilain pihak, pencemaran udara disebabkan oleh berbagai gas dan racun yang dikeluarkan oleh industri dan pabrik-pabrik serta sisa pembakaran bahan bakar fosil; pencemaran tanah terutama disebabkan oleh limbah industri yang merusak unsur hara dan zat nutrisi di tanah yang penting bagi tumbuhan.

Perubahan iklim atau pemanasan global. Perubahan iklim seperti pemanasan global adalah hasil dari praktik manusia seperti emisi gas rumah kaca. Pemanasan global menyebabkan meningkatnya suhu lautan dan permukaan bumi sehingga menyebabkan mencairnya es di kutub dan kenaikan permukaan air laut. Ia juga mengubah pola alami musim dan curah hujan seperti terjadinya banjir bandang, salju berlebihan atau penggurunan. Akibat perubahan cuaca tersebut,

${ }^{3}$ Cecep Dani Sucipto, Tehnologi Pengelolaan Daur Ulang Limbah Sampah, (Jakarta: Goysen Publishing, 2009), h. 2-3. 
produksi pertanian sering mengalami gagal panen dan memperbesar peluang terjadinya kebakaran hutan akibat terjadinya musim kering berkepanjangan.

Permasalahan lingkungan hidup selanjutnya adalah pembuangan limbah. Hal ini terutama limbah plastik dan sampah perkotaan seperti pembuangan sampah di sungai di kota-kota di Indonesia. Limbah rumah tangga, limbah dari sektor industri yang sering dibuang ke sungai juga menyebabkan ikan-ikan mati dan hancurnya ekosistem sungai. Padahal sungai-sungai ini penting bagi ekonomi masyarakat dan penting untuk memasok sumber makanan bagi masyarakat. Pembuangan limbah ini akhirnya akan menyebabkan pencemaran laut. dan merusak ekosistem laut, sumber perikanan. Plastik, makanan cepat saji, kemasan dan limbah elektronik murah mengancam kesehatan hidup manusia. Pembuangan limbah merupakan salah satu masalah lingkungan hidup yang mendesak untuk segera dicarikan jalan keluar.

Untuk mengatasi permasalahan pencemaran lingkungan haruslah menjadi tanggung jawab bersama semua komponen masyarakat termasuk akademisi di lingkungan kampus. Kampus UIN Raden Intan Lampung yang telah memperoleh penghargaan Kampus terbersih di lingkungan Perguruan Tinggi Negeri Agama Islam, sudah seharusnya menjadi bagian dalam memberikan contoh dalam pengelolaan lingkunan yang baik dan berkelanjutan. Manusia adalah komponen lingkungan hidup yang paling dominan dalam mempengaruhi lingkungan. Sebaliknya lingkungan pun mempengaruhi manusia. Sehingga terdapat hubungan yang saling pengaruh-mempengaruhi antar manusia dan lingkungan hidupnya. Hal demikian, merupakan interaksi antara manusia dan lingkungan. Apabila fungsi dalam mata rantai ekosistem tersebut terganggu dan gangguan itu melampaui kemampuan ekosistem untuk memulihkan diri secara alami, maka akan terjadilah masalah lingkungan hidup. ${ }^{4}$

Pengelolaan lingkungan hidup di atur dalam Undang-undang nomor 23 tahun 1997 tentang Pengelolaan Lingkungan Hidup.Hak, Kewajiban dan Peran Masyarakat dalam Pengelolaan lingkungan hidup tercantum dalam pasal Pasal 5, 6, dan 7. Kampus sebagai salah satu miniatur masyarakat yang terdiri dari para akademisi kaum terpelajar dan intelektual, sudah semestinya pengembangan keilmuan disertai dengan pengembangan etika sosial, berupa kepedulian terhadap keberadaan lingkungan sosial dan lingkungan alam (fisik).Untuk melestarikan dan menjaga lingkungan hidup di area kampus harus melibatkan semua unsur pengguna kampus. Karena itu penelitian ini merupakan Action Reseacrh atau Riset Aksi Partisipatoris yang akan melibatkan berbagai komponen anggota civitas sebagai pengguna kampus, antara lain:Petugas Kebersihan Kampus, Mahasiswa UIN Raden Intan/Lembaga Mahasiswa dan UKM Kampus, Karyawan bidang Rumah Tangga, penanggung Jawab pemeliharaan Kampus, dan Para tenaga Dosen dan Tendik.

4 Harun M. Husein, Lingkungan Hidup Masalah; Pengelolaan dan Penegakan Hukumnya, (Jakarta, PT Bumi Aksara, 1993), h. 16-17. 
Keterlibatan mereka sesuai dengan tanggung jawab masing-masing sebagai warga kampus untuk bersama-sama menjaga eco-sistem lingkungan kampus agar kampus tetap indah, asri dan nyaman. Untuk menjaga lingkungan kampus menjadi kampus yang bersih, tertib, nyaman dan asri, dapat dirumuskan masalah sebagai berikut:

1. Bagaimana upaya membangun kesadaran civitasakademika dalam partisipasi menjaga lingkungan kampus?

2. Bagaimana keterlibatan tenaga tendik, karyawan dan petugas kebersihan dalam partisipasinya menjaga lingkungan kampus?

\section{B. Pembahasan}

\section{Upaya Membangun Kesadaran Civitas akademika dalam Partisipasi Menjaga Lingkungan Kampus}

Pelestarian lingkungan hidup di kampus harus melibatkan seluruh elemen civitasakademika dalam partisipasi menjaga lingkungan kampus bukan hanya tanggung jawab elemen tertentu saja. Seberapa banyak usaha yang dilakukan oleh elemen tertentu dalam melestarikan lingkungan hidup akan sia-sia manakala tidak didukung oleh elemen lainnya. Seluruh elemen dalam kampus perlu menyadari bahwa akan banyak manfaatnya melestarikan lingkungan hidup untuk kehidupan manusia.

Lingkungan hidup merupakan segala sesuatu yang ada disekitar manusia, meliputi unsur biotik, abiotik, dan unsur sosial budaya,dan memiliki hubungan timbal balik dengan manusia dan perilakunya. Unsur biotik merujuk pada komponen yang memiliki ciri ciri makhluk hidup, termasuk manusia, hewan, dan tumbuhan. Unsur abiotik merujuk kepada komponen tidak hidup, berupa batubatuan, tanah, air, iklim, dan sebagainya. Sedangkan unsur sosial budaya merujuk pada keyakinan, norma, nilai dalam masyarakat, dan sebagainya. Ketiga unsur lingkungan hidup saling berhubungan yang memberi manfaat dan merupakan warisan budaya yang perlu dilestarikan. ${ }^{5}$

Berikut adalah upaya pelestarian lingkungan hidup adalah sebagai berikut:

\section{a. Mencanangkan program pengembangan berkelanjutan}

Sebagai upaya untuk mewujudkan dan melestarikan kehidupan kampus yang sejuk nan-asri perludicanangkan program pengembangan berkelanjutan berwawasan lingkungan. Program ini merupakan upaya peningkatan kualitas kehidupan kampus dengan tetap memperhatikan faktor lingkungan. Upaya ini sangat penting dalam konsep pengembangan berkelanjutan yaitu: 1) gagasan kebutuhan untuk masyarakat kampus dalam memenuhi terwujudnya kampus yang nyaman, dan 2) gagasan

5 https://www.kompasiana.com/wildensyah/55001a79a333119a7250fb87/mewujudkankampus-berwawasan-lingkungan-eco-campus?page=all, diakses pada 18 Agustus 2020. 
keterbatasan lingkungan dalam memenuhi kebutuhan kehidupan kampus yangnyamandimasa sekarang dan masa depan. ${ }^{6}$

\section{b. Mengeluarkan Aturan tentang lingkungan hidup}

Upaya pimpinan dalam pelestarian lingkungan dapat dilihat dengan dikeluarkannya aturan-aturan yang berkaitan dengan lingkungan hidup, diantaranya: 1) tidak boleh buang sampah sembarangan, buanglah sampah pada tempatnya, 2) dilrang merokok di lingkungan kampus, 3) jum'at bersih, semua warga kampus kerja bakti untuk kebersihan kampus, 4) untuk mengetasi mengenai perubahan iklimadanya penanaman pohon, 5) aturan tentang pengumpulan/pengelolaan sampah, dan 6) turan tentang pemburuan satwa liar mengenai burung kampus.

\section{c. Membentuk Badan Pengendalian Lingkungan}

Upaya pimpinan kampus membentuk suatu badan khusus untuk melakukan pengendalian dan pelestarian lingkungan hidup. Tugas pokok dari Badan Pengendalian Lingkungan adalah 1) menanggulangi kasus pencemaran, baik pencemaran udara, pencemaran tanah, maupun pencemaran air, 2) mengawasi bahan berbahaya dan beracun, 3) melakukan analisis mengenai dampak lingkungan.

\section{d. Tidak membuang limbah sembarangan}

Membuang sampah sembarangan akan membawa akibat buruk bagi kehidupan kampus, selain pemandangan tidak baik juga menimbulkan bau tidak sedap. Sampah plastik misalnya, sulit untuk didegradasi dan biasanya menumpuk membuat bau tidak sedap yang akan menimbulkan penyakit. Saat hujan datang, aliran terhalang sampah sehingga aliran air membelok keluar dari aliran yang seharusnya. Selain menjadi penyebab banjir, dampak sampah plastik bagi kesehatan juga cukup beresiko.

\section{e. Mengurangi pencemaran udara}

Dampak dari pencemaran udara yangtidak hanya menimpa manusia tetapi juga dapat mencemari lingkungan hidup. Pencemaran udara utamanya berasal dari berbagai asap yang dapat merusak lingkungan dan berdampak negatif bagi kehidupan. Adanya pencemaran udara yang tinggi terlihat banyak kabut yang menutupi cahaya matahari yang akan mengakibatkan pencemaran lingkungan dan menimbulkan kehidupan tidak sehat. Untuk mengurangi pencemaran udara di antaranya menanam pohon: Penanaman pohon adanya sikap pribadi dalam memperhatikan lingkungan, hal ini akanadanya penahanan tanah akibat banjir. Dengan adanya penahan tanah terhadap air hujan, maka

${ }^{6}$ Moh. Mukri (Rektor UINRIL), Sambutan Pada Loka Karya Nasional Kampus Hijau, Hotel Emersia Bandar Lampung, tanggal 14 Agustus 2019. 
kemungkinan tidak akan terjadi bencana banjir/longsor. Dengan melakukan penanaman pohon-pohon buah atau tanaman hias disekitar kampus, akan membantu tanah untuk meresap air, lingkungan sekitar kampus terlihat lebih hidup dengan adanya pepohonan.

\section{f. Tidak melakukan perburuan burung liar kampus dan perusakan alam}

Pemburuan burung liar dan perusakan alam memiliki dampak negatif bagi kehidupan lingkungan. Alam dan makhluk seisinya adalah suatu unsur dalam lingkungan hidup yang saling berinteraksi dan mengalami hubungan timbal balik. Untuk itu perlu disadari bahwa dengan merusak alam dengan melakukan penebangan ilegal, perburuan liar, hingga perusakan alam akan merusak tatanan kehidupan asri dan akan berimbas pada kehidupan yang sangat buruk.

\section{Melakukan sosialisasi lingkungan hidup}

Untuk pelestarian lingkungan hidup, pihak rektorat telah memiliki program pemeliharaan lingkungan hidup yang disosialisasikan kepada masyarakat/warga kampus melalui penyuluhan dengan tujuan agar masyarakat/warga punya kesadaran untuk melestarikan lingkungan. Sebagai contoh masyarakat diberikan sosialisasi mengenai ciri lingkungan sehat dan tidak sehat. Setelah sosialisasi selesai, dibuat kegiatan atau lomba rumah sehat.Sehingga masyarakat antusias dan terbiasa berpartisipasi dalam melestarikan lingkungan dalam kehidupan seharihari.

\section{Keterlibatan Dosen, Mahasiswa, Karyawan, dan Petugas Kebersihan Dalam Partisipasinya Menjaga Lingkungan Kampus}

Peran dosen, karyawan dan petugas kebersihan dalam partisipasinya dalammenciptakan lingkungan kampus sangat dibutuhkan untuk menjadi kampus yang bersih, tertib, nyaman dan asri. Kebutuhan itu untuk melakukan kerjasama secara sinergis di antara mereka dalam menciptakan kualitas lingkungan kampus yang lebih baik. Dosen, karyawan dan petugas kebersihan perlu dikembangkan dan ditingkatkan kualitas keterlibatannya untuk menyatukan semua unsur dalam sebuah sistem dalam pengelolaan dan menjaga lingkungan kampus. Pengelolaan kampus dalam upaya pelestaria lingkungan tidak hanya kampus dipenuhi dengan pepohonan, namun adanya pemanfaatan secara maksimal sumber daya manusia yang ada. Hal itu akan dapat dimanfaatkan sebagai pendorong dan sekaligus sebagai sarana penunjang pelaksanaan pendidikan, penelitian, dan pengabdian pada masyarakat. 


\section{a. Keterlibatan Dosen dan Mahasiswa dalam partisipasinya menjaga lingkungan kampus}

Dengan adanya program penghijauan di kampus para dosen mensikapinya dengan rasa senang karena akan menambah rasa suasana bersih, nyaman, sejuk, dan menyenangkan. Ditambah lagi beberapa fasilitaskampus diberbagai tempatsedang ada tambahan dan perbaikan mengarah pada mutuperbaikan secara kuantitas dan kualitas yang lebih baik dan sempurna.7 Disampingitu, berkat adanya ketrampilan mengajar dosen yang dihubungkan dengan penghijaun kampus banyak berpengaruh pada motivasi mahasiswa dalam menjaga lingkungan kampus. Sang dosen melalui ketrampilan mengajarnya telah banyak mengkaitka cara-cara menciptakan eko-kampus berbasis lingkungan yang asri. ${ }^{8}$ Juga telah ditunjukkan jalinan interaksi antara dosen dan mahasiswa dengan jalinan yang harmonis untuk dapat lebih mudah membicarakan hal-hal yang berhubungan dengan penghijuan kampus. ${ }^{9}$

Keterlibatan dosenterhadapkebersihanruangan kuliahditunjukkan dengan memberikan pengarahan pada mahasiswa pada kepeduliannya terhadap kebersihanruangan perkuliahan. Sering kali dosen menghimbauparamahasiswaagar selalu perdulidengan aturan-aturan kampus dalam menjaga kebersihan. Melakukan dan menjaga ketertiban langsung atau tidak langsung telah melakukan dan menjaga kebersihan ruang perkuliahan atau tempat belajar. Cara seperti ini yang telah ditunjukkan dosen memberi kesan bahwa dosen memberi contoh langsung untuk secara bersama-sama dengan para mahasiswa membersihkan ruangan perkuliahan yang ada. Kondisi semacam ini akan sangat membantu menciptakan lingkungan bersih sesuai dengan aturan yang telah sosialisasikan oleh pimpinan.

Perkuliahan atau tempat belajar. Cara yang ditunjukkan dosen mengajak mereka dengan contoh langsung untuk secara bersama-sama dengan paramahasiswa membersihkan ruangan perkuliahan. Terdapat keterlibatan dosen yang memiliki kepedulian dalam lingkungan kampus memberikan arahan pada mahasiswa yang kedapatan membuang sampah sembarangan dan menegurnya agar membuang sampah pada tempatnya.

Kesadaran dosen ikut serta dalam menjaga kebersihan kamar mandi kampus agar dapat nyaman menggunakannya.Ketika para dosen melihat toilet atau kamar mandi yang kotor dan menimbulkan bau tidak sedap, sudah berulang kali melaporkan pada pihak pimpinan fakultas

7 Erjati Abas (Dosen Fak. Tarbiyah dan Keguruan UINRIL), Hasil Wawancara, tanggal 25 September 2020

8 M. Syaefuddin (Dosen Fak. Dakwah dan Ilmu Komunikasi UINRIL), Hasil Wawancara, tanggal 25 September 2020.

9 Sunarto, (Dosen Fak. Tarbiyah dan Keguruan UINRIL), Hasil Wawancara, tanggal 25 September 2020. 
yang berwenang. Akan tetapi laporan itu belummendapatkanrespon positifdari pimpinan untuk menindak lanjutinya.Tidak kalah pentingnya juga dosen banyak memberikan peringatan pada mahasiswa yang acuh tak acuh dengan aturan yang telah dikeluarkan oleh pihak kampus.

Keterlibatan Mahasiswa dalam partisipasinya menjaga lingkungan kampus dalam kategori baik.Kecenderungan mahasiswa yang memiliki sikap positif ditunjukkan dengan memulai kebersihan lingkungan dari diri sendiri, dan mengajak teman sesamanya untuk menjaga lingkungan tetap bersih. Juga banyak mahasiswa yang memberikan peringatan pada temannya yang tidak peduli pada kebersihan lingkungan kampus. Sementara itupula adanya mahasiswa yang memiliki sikap peduli pada kebersihan kamar mandi, yaitu mahasiswa tersebut menghimbau temannya untuk menjaga kebersihan agar nyaman dalam menggunakannya atau memanfaatkannya.

Mereka mengajak kepada para mahasiswa untuk benar-benar dapat menjaga kebersihan ruangan perkuliahan. ${ }^{10}$ Hal ini menandakan bahwa, keterlibatan mahasiswa nyata dalam menjaga kebersihan bukan hanya di luar ruangan, tetapi juga dalam ruang lingkup kebersihan ruangan perkuliahan, dan ruang kamar mandi.

Ada agenda yang dilakukan oleh UKM mahasiswa dan mahasiswa Fakultas Tarbiyah Jurusan Biologi UINRIL melakukan kegiatan pengelolaan sampah plastik sekitar kampus. Pengelolaan sampah merupakan kegiatan yang menuntut perhatian berbagai pihak termasuk di dalamnya adalah para mahasiswa dalam upaya melestarikan lingkungan kehidupan kampus yang asri. Sampah merupakan barang yang tetap ada selama masih ada kehidupan. Pengelolaan sampah, para mahasiswa aktivis lingkungan yang menempuh pendidikan Biologi lingkungan telah melakukan kegiatan 3R yang meliputi: reuse (menggunakan kembali), reduce (mengurangi), dan recycle (mendaur ulang). ${ }^{11}$

\section{b. Keterlibatan karyawan dalam partisipasinya menjaga lingkungan kampus}

Salah satu tugas karyawan dalam kampus adalah ikut serta memiliki peran untuk menjaga dan mengembangkan kebersihan kampus. Peran karyawan tidak diragukan lagi sehingga tidaklah berlebihan dan aneh jika banyak para karyawan berperan aktif dalam pelestarian lingkungan kampus, sehingga peranan seorang karyawan sangatlah penting dalam menjaga kebersihan di lingkungan kampus. Sudah

10 Novita Sari (Mahasiswa Fak. Dakwah dan Ilmu Komunikasi UINRIL), Hasil Wawancara, tanggal 12 Agustus 2020.

11 Eko Kuswanto (Ketua TPKBBL: Tim Pengembangan Kampus Berkelanjutan dan Berwawasan Lingkungan), Hasil Wawancara, tanggal 15 September 2020. Juga Dapat dibaca: UKM Maharipal Kampanyekan Diet Plastik, Pada Majalah Raden Intan tentang: Teguhkan Komitmen Kampus Hijau /Green Campus UIN Raden Intan Lampung, Edisi XXII, Tahun 2019, h. 37. 
sepatutnya kebersihan lingkungan kampus karyawan ikut andil dalam tanggung jawab dalam kebersihan kampus agar sampah tidak menumpuk dan mencemari lingkungan. ${ }^{12}$

Menjaga kebersihan kampus sangatlah penting, kebersihan merupakan ajaran agama dan sekaligus sebagai tuntutan bagi Kampus yang isinya masyarakat berilmu. Para karyawan sudah sejak lama ditanamkan kesadaran untuk tetap menjaga kebersihan lingkungan kampus. Lingkungan yang bersih dapat menambah semangat serta kenyamanan dalam proses belajar mengajar. Mereka sangat gigih dalam mengimplementasikan slogan kampus yang bersih dari sampah dan hampir tidak pernah ditemukan puntung rokok maupun sampah di lingkungan Kampus.

c. Keterlibatan petugas kebersihan dalam partisipasinya menjaga lingkungan kampus

Petugas kebersihan memiliki tugas mengurusi kebersihan membersihkan dan membuang sampah kampus, mulai dari menyapu sampai mengangkut sampah dan membuangnya serta membuat kompos untuk pupuk tanaman kampus.13 Diketahui bahwa jumlah petugas kebersihan sangat terbatas dibanding dengan luas lahan yang ada, untuk itu diminta kesadaran setiap individu untuk menjaga kebersihan dan tidak hanya mengandalkan petugas kebersihan saja. Ketua yang membidangi penjagaan lingkungan kampus Eko Suwan to menyampaikan dan memberikan pemahaman bahwa petugas kebersihan untuk terus berkomitmen menjaga lingkungan kampus, menjaga sirkulasi udara, pengelolaan sampah terus digalakkan agar lingkungan kampus tetap bersih, asri dan sejuk. ${ }^{14}$

Untuk menunjang keberhasilan kebersihan kampus pimpinan rektorat dan fakultas telah berupaya dalam penambahan jumlah tempattempatsampah yang diperlukan. Hal inidapatdijadikanpemecahanma salah dalam mengatasi keterbatasan petugas kebersihan kampus agar terjaga dengan baik. Petugas kebersihan telah diatur dan disebar keberbagai lingkungan kampus agar tetap bersih sesuai dengan aturan baik secara kuantitas mapun kualitasnya. ${ }^{15}$

12 Hayatul Islam (Kabag Humas dan Redaktur Pelaksana Majalah Raden Intan UINRIL), Hasil Wawancara, tanggal 10 September 2020.

${ }_{13}$ Nanda, Andre, Hendrik, dan Bambang (Anggota OB UINRIL), Hasil Wawancara, tanggal 15 Agustus 2020.

14 Eko Kuswanto (Ketua TPKBBL: Tim Pengembangan Kampus Berkelanjutan dan Berwawasan Lingkungan), Hasil Wawancara, tanggal 15 September 2020.

15 Dailin, (Wakil Ketua Saptam dan OB UINRIL), Hasil Wawancara, tanggal 10 September 2020, dan H. Iqbal Madri Fahda, S.Ag., M.M., (Plt. Kabag. TU Fak Dakwah dan Ilmu Komunikasi UINRIL), Hasil Wawancara, tanggal 15 September 2020. 
Penambahan jumlah tempat sampah di UINRIL merupakan yang hal yang sangat penting dan mendasar untuk menjaga agar kampus tetap bersih dan asri. Pengadaan tempat sampah dilakukan oleh pihak universitas maupun pihak fakultas yang telah memiliki berbagai kebijakan yang ada. Tempat sampah yang ada dilakukan pemisahan pembuangannya yaitu tempat sampah organik dan tempat sampah unorganik. Penambahan tempat sampah banyak pula manfaatnya dari segi penempatan dan penataan tempat sampahnya sendiri yang lebih rapi dan strategis. Ini semua akan mempermudah orang-orang untuk membuang sampah dan mengasah kesadaran berlingkungan yang mengedepankan kampus yang bersih, asri, sejuk, dan nyaman.

\section{Simpulan}

Mewujudkan kampus hijau yang berkelanjutan perlu adanya keteguhan komitmen baik pihak pimpinan kampus maupun seluruh elemen warga kampus. Untuk menjadikan kampus hijau, asri, dan berwawasan lingkungan, harus dibarengi dengan ikhtiar, langkah-langkah strategis, dan teknis tertentu terus dikerjakan secara kontinyu. Implementasi nilai-nilai pelestarian lingkungan dalam kehidupan yang dilakukan oleh Civitas Academika UIN Raden Intan Lampung melalui berbagai cara yang dapat dipahami oleh berbagai elemen. Dengan demikian dalam penelitian ini, sesuai dengan data yang diperoleh dan analisis yang dilakukan, penulis mengambil kesimpulan sebagai berikut. Pertama, upaya membangun kesadaran civitas akademika dalam partisipasi menjaga lingkungan kampus dengan mencanangkan program pengembangan berkelanjutan, mengeluarkan Aturan tentang lingkungan hidup, membentuk Badan Pengendalian Lingkungan, tidak membuang limbah sembarangan, mengurangi pencemaran udara, tidak melakukan perburuan burung liar kampus dan perusakan alam, dan melakukan sosialisasi lingkungan hidup. Kedua, keterlibatan mahasiswa dalam partisipasinya menjaga lingkungan kampus. Kecenderungan partisipasi mahasiswa ditunjukan dengan memulai kebersihan lingkungan diri sendiri dan mengajak temannya untuk menjaga kebersihan. Juga mahasiswa memiliki sikap peduli kebersihan kamar mandi. Hal ini menandakan bahwa, keterlibatan mahasiswa nyata dalammenjagakebersihan bukanhanya di luar ruangan, tetapi juga dalam ruang lingkup kebersihan ruangan perkuliahan, dan ruangan toilet atau kamar mandi. Ketiga, keterlibatan karyawan dalam partisipasinya menjaga lingkungan kampus. Salah satu tugas karyawan dalam kampus adalah ikut serta memiliki peran untuk menjaga dan mengembangkan kebersihan kampus. Peran karyawan tidak diragukan lagi sehingga tidaklah berlebihan dan aneh jika banyak para karyawan berperan aktif dalam pelestarian lingkungan kampus, sehingga peranan seorang karyawan sangatlah penting dalam menjaga kebersihan di lingkungan kampus. Menjaga kebersihan kampus sangatlah penting, kebersihan merupakan ajaran agama dan sekaligus sebagai 
tuntutan bagi Kampus yang isinya masyarakat berilmu. Para karyawan sudah sejak lama ditanamkan kesadaran untuk tetap menjaga kebersihan lingkungan kampus. Lingkungan yang bersih dapat menambah semangat serta kenyamanan dalam proses belajar mengajar. Mereka sangat gigih dalam mengimplementasikan slogan kampus yang bersih dari sampah dan hampir tidak pernah ditemukan puntung rokok maupun sampah di lingkungan Kampus. Keempat, keterlibatan petugas kebersihan dalam partisipasinya menjaga lingkungan kampus. Petugas kebersihan memiliki tugas mengurusi kebersihan membersihkan dan membuang sampah kampus, mulai dari menyapu sampai mengangkut sampah dan membuangnya.Dan penjagaan lingkungan kampus dipahami bahwa petugas kebersihan terus berkomitmen menjaga lingkungan kampus, menjaga sirkulasi udara, pengelolaan sampah terus digalakkan agar lingkungan kampus tetap bersih, asri dan sejuk.

\section{Referensi:}

Cecep Dani Sucipto, Tehnologi Pengelolaan Daur Ulang Limbah Sampah, Jakarta: Goysen Publishing, 2009.

Harun M. Husein, Lingkungan Hidup Masalah; Pengelolaan dan Penegakan Hukumnya, Jakarta, PT Bumi Aksara, 1993.

https://www.academia.edu/18121109/Materi_Karakteristik_Sistem

https://www.kompasiana.com/wildensyah/55001a79a333119a7250fb87/mewuj udkan-kampus-berwawasan-lingkungan-eco-campus?page $=$ all

Moh. Mukri (Rektor UINRIL), Forum Kampus Hijau PTKI Terbentuk, dalam Majalah Raden Intan UINRIL, Edisi XXII, Tahun 2019.

Moh. Mukri (Rektor UINRIL), Sambutan Pada Loka Karya Nasional Kampus Hijau, Hotel Emersia Bandar Lampung, tanggal 14 Agustus 2019. 